\title{
NOTE
}

\section{Aeromonas salmonicida ssp. salmonicida lacking pigment production, isolated from farmed salmonids in Finland}

\author{
Tom Wiklund, Lars Lönnström, Hillevi Niiranen \\ Institute of Parasitology, Åbo Akademi University, BioCity, Artillerig. 6, SF-20520 Åbo, Finland
}

\begin{abstract}
Strains of Aeromonas salmonicida ssp. salmonicida lacking pigment production were isolated from brown trout Salmo trutta m. lacustris and sea trout $S$. trutta m. trutta cultivated in fresh water in south Finland. The bacteria isolated showed only minor deviations in biochemical characteristics compared to 2 strains of $A$. salmonicida ssp. salmonicida and the type strain of $A$. salmonicida ssp. salmonicida (NCMB 1102). Several characters differed when compared to the type strain of A. salmonicida ssp. achromogenes (NCMB 1110). In challenge experiments, the strain tested was highly pathogenic to rainbow trout Oncorhynchus mykiss.
\end{abstract}

Different forms of Aeromonas salmonicida are frequently isolated from diseased salmonids as well as from non-salmonids (Wichardt 1983, Böhm et al. 1986 , Wiklund 1990). Traditionally $A$. salmonicida has been divided into typical strains, that is, ssp. salmonicida which produce a brown water-soluble pigment and 'atypical' strains which do not produce or only very slowly produce the brown pigment. The 'atypical' strains include $A$. salmonicida ssp. achromogenes, $A$. salmonicida ssp. masoucida, and several isolates not readily assigned to any of the valid subspecies. Recently a fourth subspecies, A. salmonicida ssp. smithia, which does not readily produce the brown pigment, was proposed by Austin et al. (1989).

According to 'Bergey's Manual of Systematic Bacteriology' (Popoff 1984) the production of brown pigment is one of the 9 key characteristics in separating ssp. salmonicida from 'atypical' strains (Table 1). The present paper, however, describes strains of Aeromonas salmonicida ssp. salmonicida lacking pigment production.

During routine examination of diseased farmed fish in our laboratory in 1991, non-pigmented variants of Aeromonas salmonicida were isolated from brown trout Salmo trutta m. lacustris and sea trout S. trutta m. trutta from 4 fish farms using fresh water. The fish farms, which were located in south Finland, were mainly raising smolts for stocking purposes.

Table 1. Differential characteristics of subspecies of Aeromonas salmonicida and corresponding results of the non-pigmented strains. +: positive reaction; -: negative reaction; NT: not tested

\begin{tabular}{|c|c|c|c|c|c|}
\hline \multirow[t]{2}{*}{ Characteristic } & \multirow{2}{*}{$\begin{array}{l}\text { Present } \\
\text { strains }\end{array}$} & \multicolumn{4}{|c|}{ Aeromonas salmonicida } \\
\hline & & $\begin{array}{l}\text { ssp. } \\
\text { salmonicida }^{\text {a }}\end{array}$ & $\begin{array}{c}\text { ssp. } \\
\text { achromogenes }\end{array}$ & $\begin{array}{c}\text { ssp. } \\
\text { masoucida }\end{array}$ & $\begin{array}{l}\text { ssp. } \\
\text { smithia }^{\mathrm{b}}\end{array}$ \\
\hline Brown pigment & - & + & - & - & $+/-$ \\
\hline Indole production & - & - & + & + & - \\
\hline Esculin hydrolysis & + & + & - & + & - \\
\hline L-Arabinose utilization & NT & + & - & + & - \\
\hline Acid from sucrose & - & - & + & + & $+1-$ \\
\hline Acid from mannitol & + & + & - & + & $+/-$ \\
\hline Voges-Proskauer & - & - & - & + & - \\
\hline Gas from glucose & + & + & - & + & NT \\
\hline Production of $\mathrm{H}_{2} \mathrm{~S}$ & - & - & - & + & + \\
\hline
\end{tabular}


The total mortality of the affected fish stock in one of the farms was about $90 \%$. Disease signs in the fish from this farm were more pronounced than in fish from the other farms: large necrotic lesions in the muscles, enlarged spleens, and hemorrhagic intestines. The total mortality in the other farms varied from 8 to $40 \%$. The disease signs of the fish from these farms included minor skin ulcers, enlarged spleens, and petechial hemorrhages in the perivisceral adipose tissue.

The diseased fish in one of the farms were medicated with oxytetracycline. On 2 other farms the fish were treated with oxolinic acid. Mortality ceased during the medication period.

Material and methods. Two to eleven fish from each farm $(n=4)$ were examined for bacterial infection in visceraì organs. Samples írom kidney, iver, and spleen from the diseased fish were inoculated onto tryptic soy (TS) agar (Difco Laboratories; final $\mathrm{NaCl}$ concentration $=1.5 \%$ ), supplemented with $5 \%$ bovine blood. The agar plates were incubated at $20^{\circ} \mathrm{C}$ for $7 \mathrm{~d}$. Biochemical tests were carried out on the isolates using methods described by MacFaddin (1983) or Cowan (1974) and the API 50 CHE diagnostic system (Bio Merieux, France). Because the development of brown pigment was previously shown to be dependent on tyrosine and phenylalanine (Griffin et al. 1953), TS agar supplemented either with tyrosine or phenylalanine $(0.1 \%$ final concentration) was used to detect the pigment production.

As reference strains we included one pigmentforming strain (isolated concurrently with one of the non-pigmented strains), one strain of Aeromonas salmonicida ssp. salmonicida isolated from diseased farmed rainbow trout Oncorhynchus mykiss, and type strains of $A$. salmonicida ssp. salmonicida (NCMB 1102 ) and $A$. salmonicida ssp. achromogenes (NCMB 1110).

Virulence tests with one of the non-pigmented strains were performed by intraperitoneally injecting rainbow trout ( 5 fish per concentration) with $0.1 \mathrm{ml}$ sterile saline $(0.9 \% \mathrm{NaCl})$ containing $1.3 \times 10^{7}, 1.3 \times$ $10^{5}$, and $1.3 \times 10^{3}$ washed bacteria (CFU, colonyforming units). Control fish were injected with $0.1 \mathrm{ml}$ sterile saline. The infected fish were kept in recirculating, filtered tap water at 16 to $17^{\circ} \mathrm{C}$ for 2 wk. Samples of spleen, kidney, and liver from dead and surviving fish were examined bacteriologically.

Results. Gram-negative, non-motile, cytochrome oxidase-positive, facultatively anaerobic, short rods were isolated from the examined fish. Pigmented ( 3 isolates out of 7 ) as well as non-pigmented ( 4 isolates out of 7) strains were isolated from diseased fish from one of the farms. The strains isolated from the other 3 farms were all non-pigmented, and they were isolated from 67 to $100 \%$ of the examined fish.
In the biochemical tests, the strains lacking pigment production were almost identical to the 2 pigmentforming co-isolates tested and they all showed only minor deviations (growth in $4 \% \mathrm{NaCl}$ and at $30^{\circ} \mathrm{C}$ ) from the type strain of Aeromonas salmonicida ssp. salmonicida (NCMB 1102). Compared to the type strain of A. salmonicida ssp. achromogenes (NCMB 1110), several different characters (19 out of 92) were encountered (Table 2). However, the strain NCMB 1110 gave a positive reaction in the VP test, although it should have been negative according to Popoff (1984).

The strains tested did not produce pigment on TS agar supplemented with phenylalanine, but after 6 to $7 \mathrm{~d}$ of incubation a very weak pigment production was noted on TS agar supplemented with tyrosine. The Aeromonas salmonicida ssp. salmonicida reference strains produced pigment on both agars.

In the challenge test all fish injected with $1.3 \times 10^{7}$ and $1.3 \times 10^{5}$ bacteria died within $3 \mathrm{~d}$, and 4 fish oul of 5 injected with $1.3 \times 10^{3}$ bacteria died within $5 \mathrm{~d}$. One fish survived for $2 \mathrm{wk}$ in the last-mentioned group. All fish in the control group were alive at the end of the experiment. The injected bacteria were re-isolated from visceral organs of all dead fish but not from the one surviving challenged fish. These isolates did not produce any pigment on TS agar.

During 1992, the same type of disease occurred in 3 of the previously affected farms, but unfortunately no attempt to isolate bacteria was made. On the fourth farm there were no disease outbreaks during 1992. However, in 1992 non-pigmented strains of Aeromonas salmonicida ssp. salmonicida were isolated from diseased fish on 2 previously unaffected farms. One of the three of these non-pigmented variants tested did not produce gas from glucose and two of them produced acid from trehalose. In all other biochemical tests they were similar to the non-pigmented strains isolated in 1991 .

Discussion. To our knowledge there are very few reports of 'typical' Aeromonas salmonicida strains that do not produce a brown, water-soluble pigment when grown on agar containing tryptone (tyrosine or phenylalanine). Austin et al. (1989) reported one strain of A. salmonicida ssp. salmonicida out of 27 tested ( $4 \%$ ) not producing pigment. However, several characteristics of the group described (see Austin et al. 1989) did not match the type description of $A$. salmonicida ssp. salmonicida (Popoff 1984). Evelyn (1971) reported an aberrant strain of $A$. salmonicida that lost its ability to produce pigment after 2 yr of subcultivation. Also, Duff \& Stewart (1933) noticed that isolates lost their ability to produce the brown pigment after prolonged subcultivation. Conversely, one strain recovered from an experimentally infected goldfish was reported not to produce brown pigment until it was subcultured 5 times. 
Table 2. Morphological and biochemical characteristics of non-pigmented and pigmented Aeromonas salmonicida ssp. salmonicida strains and of type strains NCMB 1102 (A. salmonicida ssp. salmonicida) and NCMB 1110 (A. salmonicida ssp. achromogenes). ASS: A. salmonicida ssp. salmonicida; ASA: A. salmonicida ssp. achromogenes. +: positive reaction; -: negative reaction; $(+)$ : weak reaction; $R$ : resistant; S: sensitive

\begin{tabular}{|c|c|c|c|c|}
\hline & $\begin{array}{c}\text { Non-pigmented } \\
\text { ASS } \\
(\mathrm{n}=4)^{a}\end{array}$ & $\begin{array}{l}\text { Pigmented } \\
\text { ASS } \\
(\mathrm{n}=2)^{\star}\end{array}$ & $\begin{array}{c}\text { ASS } \\
\text { NCMB } \\
1102\end{array}$ & $\begin{array}{l}\text { ASA } \\
\text { NCMB } \\
1110\end{array}$ \\
\hline Gram stain & - & - & - & - \\
\hline Cell morphology & Rod & Rod & Rod & Rod \\
\hline Motility & - & - & - & - \\
\hline Cytochrome oxidase & + & + & + & + \\
\hline Catalase & + & + & + & + \\
\hline Modified O/F test & $+/+$ & $+/+$ & $+t+$ & $+/+$ \\
\hline Arginine dihydrolase & + & + & + & + \\
\hline Lysine decarboxylase & + & + & $(+)$ & - \\
\hline Ornithine decarboxylase & - & - & - & - \\
\hline \multicolumn{5}{|l|}{ Growth in/at: } \\
\hline $0 \% \mathrm{NaCl}$ & + & + & + & + \\
\hline $3 \% \mathrm{NaCl}$ & + & + & + & + \\
\hline $4 \% \mathrm{NaCl}$ & - & - & + & + \\
\hline $5 \% \mathrm{NaCl}$ & - & - & - & - \\
\hline $4^{\circ} \mathrm{C}$ & + & + & + & + \\
\hline $30^{\circ} \mathrm{C}$ & + & + & - & - \\
\hline $37^{\circ} \mathrm{C}$ & - & - & - & - \\
\hline \multicolumn{5}{|l|}{ Susceptibility to: } \\
\hline $0 / 12910 \mu \mathrm{g}$ & $\mathrm{R}$ & $\mathrm{R}$ & $\mathrm{R}$ & $\mathrm{R}$ \\
\hline $150 \mu \mathrm{g}$ & $\mathrm{R}$ & $\mathrm{R}$ & $\mathrm{R}$ & $\mathrm{R}$ \\
\hline Oxytetracycline $(80 \mu \mathrm{g})$ & $\mathrm{S}$ & $\mathrm{S}$ & $\mathrm{S}$ & $\mathrm{S}$ \\
\hline Oxolinic acid $(10 \mu \mathrm{g})$ & $\mathrm{S}$ & $\mathrm{S}$ & $\mathrm{S}$ & $\mathrm{S}$ \\
\hline Trimethoprim + sulfa $(5.2+240 \mu \mathrm{g})$ & $\hat{S}$ & $\vec{S}$ & $\mathrm{~S}$ & $\mathrm{~S}$ \\
\hline Ampicillin $(33 \mu \mathrm{g})$ & $\mathrm{S}$ & $\mathrm{S}$ & $\mathrm{S}$ & $\mathrm{R}$ \\
\hline Cephalothin $(66 \mu \mathrm{g})$ & $\mathrm{S}$ & $S$ & $\mathrm{~S}$ & $\mathrm{R}$ \\
\hline \multicolumn{5}{|l|}{ Production of: } \\
\hline Acetoin from glucose (Voges-Proskauer) & - & - & - & + \\
\hline Brown pigment (Tryptic soy agar $3 \mathrm{~d}$ ) & - & + & + & - \\
\hline$\beta$-galactosidase (ONPG) & - & - & - & - \\
\hline Gas from glucose & + & + & + & - \\
\hline Hydrogen sulphide (SIM) & - & - & - & - \\
\hline Indole (tryptone broth) & - & - & - & + \\
\hline Phenylalanine deaminase & - & - & - & - \\
\hline Phosphatase & - & - & - & - \\
\hline Utilization of Na-citrate & - & - & - & - \\
\hline Nitrate reduction & + & + & + & + \\
\hline \multicolumn{5}{|l|}{ Degradation of: } \\
\hline Blood (haemolysis) & + & + & + & - \\
\hline Casein & + & + & + & + \\
\hline DNA & + & + & + & + \\
\hline Esculine & + & + & + & - \\
\hline Gelatine & + & + & + & - \\
\hline Starch & + & + & + & + \\
\hline Tween 80 & + & + & + & + \\
\hline \multicolumn{5}{|l|}{ Growth on: } \\
\hline Aeromonas agar & + & + & + & + \\
\hline Cytophaga agar & + & + & + & + \\
\hline MacConkey agar & + & + & + & + \\
\hline TCBS agar & - & - & - & - \\
\hline
\end{tabular}


Table 2 (continued)

\begin{tabular}{|c|c|c|c|c|}
\hline & $\begin{array}{c}\text { Non-pigmented } \\
\text { ASS } \\
(n=4)^{d}\end{array}$ & $\begin{array}{c}\text { Pigmented } \\
\text { ASS } \\
(n=2)^{d}\end{array}$ & $\begin{array}{c}\text { ASS } \\
\text { NCMB } \\
1102\end{array}$ & $\begin{array}{l}\text { ASA } \\
\text { NCMB } \\
1110\end{array}$ \\
\hline \multicolumn{5}{|c|}{ Acid production (API $50 \mathrm{CHE}$ ): } \\
\hline Glycerol & + & + & + & + \\
\hline Erythritol & - & - & - & - \\
\hline D-Arabinose & - & - & - & - \\
\hline L-Arabinose & + & + & + & - \\
\hline Ribose & + & + & + & + \\
\hline D-Xylose & - & - & - & - \\
\hline L-Xylose & - & - & - & - \\
\hline Adonitol & - & - & - & - \\
\hline$\beta$ Methyl-xyloside & - & - & - & - \\
\hline Galactose & + & + & + & $(+)$ \\
\hline D-Glucose & + & + & + & + \\
\hline D-Fructose & + & + & + & + \\
\hline D-Mãnnose & \pm & - & - & + \\
\hline L-Sorbose & - & - & - & - \\
\hline Rhamnose & - & - & - & - \\
\hline Dulcitol & - & - & - & - \\
\hline Inositol & - & - & - & - \\
\hline Mannitol & + & + & + & + \\
\hline Sorbitol & - & - & - & - \\
\hline$\alpha$ Methyl-D-mannoside & - & - & - & - \\
\hline$\alpha$ Methyl-D-glucoside & + & + & + & - \\
\hline N Acetyl glucosamine & + & + & + & - \\
\hline Amygdaline & - & - & - & - \\
\hline Arbutine & + & + & + & - \\
\hline Salicine & + & + & + & - \\
\hline Cellobiose & - & - & - & - \\
\hline Maltose & + & + & + & + \\
\hline Lactose & - & - & - & - \\
\hline Melibiose & - & - & - & - \\
\hline Saccharose & - & - & - & + \\
\hline Trehalose & - & - & - & + \\
\hline Inuline & - & - & - & - \\
\hline Melezitose & - & - & - & - \\
\hline D-Raffinose & - & - & - & - \\
\hline Amidon & + & + & + & + \\
\hline Glycogen & + & + & + & + \\
\hline Xylitol & - & - & - & - \\
\hline$\beta$ Gentiobiose & - & - & - & - \\
\hline D-Turanose & - & - & - & - \\
\hline D-Lyxose & - & - & - & - \\
\hline D-Tagatose & - & - & - & - \\
\hline D-Fucose & - & - & - & - \\
\hline L-Fucose & - & - & - & - \\
\hline D-Arabitol & - & - & - & - \\
\hline L-Arabitol & - & - & - & - \\
\hline Gluconate & + & + & + & - \\
\hline 2 ceto-gluconate & - & - & - & - \\
\hline 5 ceto-gluconate & - & - & - & - \\
\hline
\end{tabular}


On the other hand, there are reports that motile Aeromonas species and Vibrio anguillarum can produce the same type of pigment as $A$. salmonicida (Paterson 1974, Allen et al. 1983, Evelyn \& Ketcheson 1990). Recently, a strain of Pseudomonas fluorescens producing brown pigment was also reported (Frerichs \& Holliman 1991).

So far most strains of Aeromonas salmonicida not producing pigment have been considered to be 'atypical' ones and they have been assigned to the ssp. achromogenes, ssp. masoucida (Kimura 1969), ssp. smithia (Austin et al. 1989), or simply identified as 'atypical' strains. Our results show that the present isolates should not be included in ssp. achromogenes, ssp. masoucida or ssp. smithia. A comparison between the results of the present non-pigmented isolates and the key characteristics of different subspecies of A. salmonicida proposed by Popoff (1984) shows that the present isolates differ from ssp. achromogenes in 5 tests (indole production, esculin hydrolysis, acid production from sucrose and mannitol, and gas production from glucose), from ssp. masoucida in 4 tests (indole production, acid production from sucrose, Voges-Proskauer test, production of $\mathrm{H}_{2} \mathrm{~S}$ ), and from ssp. smithia (Austin et al. 1989) in 2 tests (esculin hydrolysis, production of $\mathrm{H}_{2} \mathrm{~S}$ ) (Table 1 ).

Based on our results, we conclude that the present isolates should be considered as Aeromonas salmonicida ssp. salmonicida. Thus the use of pigment production as one of the key diagnostic features for separating ssp. salmonicida from the other subspecies has to be re-evaluated. The reliability of using pigment production in diagnosing typical $A$. salmonicida has also previously been questioned (Austin \& Austin 1987).

The challenge test showed that the injected strain was highly pathogenic for rainbow trout.

The origin of the present strains is unclear, but the development of non-pigmented variants of typical Aeromonas salmonicida may be due to a mutation in pigment producing strains. This hypothesis is supported by the co-isolation of typical pigmentproducing and pigment-lacking strains from one of the farms. Fingerlings from one of the affected farms were transferred in the beginning of the summer to the 3 other affected farms and obviously the described bacterium was transferred with the fish.

Acknowledgements. We are grateful to V. Luomala for technical assistance and to Vet. V. Hirvelä-Koski (National Veterinary Institute, Regional Laboratory of Oulu) for confirming some of our results. We also thank Dr G. Bylund for valuable comments on the manuscript. We are indebted to Vet. E. Rimaila-Pärnänen for the information on some of the disease outbreaks in 1992, caused by non-pigmented variants of Aeromonas salmonicida ssp. salmonicida.

\section{LITERATURE CITED}

Allen, D. A., Austin, B., Colwell, R. R. (1983). Aeromonas media, a new species isolated from river water. Int. J. system. Bacteriol. 33(3): 599-604

Austin, B., Austin, D. A. (1987). Bacterial fish pathogens: disease in farmed and wild fish. Ellis Horwood Limited, Chichester

Austin, D. A., McIntosh, D., Austin, B. (1989). Taxonomy of fish associated Aeromonas spp., with the description of Aeromonas salmonicida subsp. smithia subsp. nov. System. appl. Microbiol. 11. 277-290

Böhm, K. H., Fuhrmann, H., Schlotfeldt, H.-J,, Körting, W. (1986). Aeromonas salmonicida from salmonids and cyprinids - serological and cultural identification. J. vet. Med. B 33: 777-783

Cowan, S. T. (1974). Cowan \& Steel's manual for the identification of medical bacteria. Cambridge University Press, Cambridge

Duff, D. C. B., Stewart, B. J. (1933). Studies on furunculosis of fish in British Columbia. Contr. Canad. Biol. Fish. 8 (8), Ser. A, Gen. Nm. 35: 103-122

Evelyn, T. P. T. (1971). An aberrant strain of the bacterial fish pathogen Aeromonas salmonicida isolated from a marine host, the sablefish (Anoplopoma fimbria), and from two species of cultured Pacific salmon. J. Fish. Res. Bd Can. 28(10): 1629-1634

Evelyn, T. P. T., Ketcheson, J. E. (1990). An unusual isolate of Vibrio anguillarum from British Columbia. FHS/AFS Newsletter 18(2): 4

Frerichs, G. N., Holliman, A. (1991). Isolation of a brown pigment-producing strain of Pseudomonas fluorescens cross-reacting with Aeromonas salmonicida diagnostic antisera. J. Fish Dis. 14: 599-601

Griffin, P. J., Snieszko, S. F., Friddle, S. B. (1953). Pigment formation by Bacterium salmonicida. J. Bacteriol. 65: $652-659$

Kimura, T (1969). A new subspecies of Aeromonas salmonicida as an etiological agent of furunculosis on 'Sakuramasu' (Oncorhynchus masou) and pink salmon (O. gorbuscha) rearing for maturity, Part 1 . On the morphological and physiological properties. Fish Pathol. 3: $34-44$

MacFaddin, J. F. (1983). Biochemical tests for identification of medical bacteria, 2nd edn. Williams \& Wilkins, Baltimore

Paterson, W. D. (1974). Biochemical and serological differentiation of several pigment-producing aeromonads. J. Fish. Res. Bd Can. 31(7): 1259-1261

Popoff, M. (1984). Genus III. Aeromonas Kluyver and Van Niel 1936, 398 AL In: Krieg, N. R., Holt, J. G. (eds.) Bergey's manual of systematic bacteriology, Vol. 1. Williams \& Wilkins, Baltimore, p. 545-548

Wichardt, U.-P. (1983). Atypical Aeromonas salmonicidainfection in sea-trout (Salmo trutta, L.) I. Epizootiological studies, clinical signs and bacteriology. Laxforskningsinst. Medd. 6: 1-10

Wiklund, T. (1990). Atypical Aeromonas salmonicida isolated from ulcers of pike, Esox lucius L. J. Fish Dis. 13: 541-544

Manuscript first received: April 23, 1992

Revised version accepted: December 10, 1992 